\title{
AL-KHIDMA
}

JURNAL PENGABDIAN MASYARAKAT

E-ISSN: 2807-7903

\section{PENDAMPINGAN WIRAUSAHA SEBAGAI BENTUK PENGEMBANGAN DIRI MAHASISWA STAIN MAJENE}

\author{
Atirah \\ Jurusan Syariah dan Ekonomi Bisnis Islam, STAIN Majene \\ atib@stainmajene.ac.id / btira390@gmail.com \\ Wahyuddin \\ Jurusan Tarbiyah dan Keguruan, STAIN Majene \\ Wahyuddin.my@stainmajene.ac.id \\ Reski Rahman Sriwijaya \\ Jurusan Agroindustri, Politeknik Negeri Fak-Fak \\ Reskirahman7@gmail.com
}

\begin{abstract}
Abstrak
Kegiatan program pelatihan singkat untuk menjadi wirausaha diharapkan untuk memaksimalkan bekal tambahan diluar jam mata kuliah kewirausahaan agar membuat mahasiswa membiasakan diri untuk berfikir kreatif dalam berusaha. Pelatihan praktek berwirausaha yang diangkat dalam kegiatan pengabdian kepada masyarakat ini bertujuan untuk memberikan pengalaman nyata kepada para mahasiswa untuk berwirausaha, yang diharapkan setelah pelatihan ini selesai memberikan stimulus untuk mahasiswa memiliki karir usaha sejak dini. Oleh karna itu, diusulkan kerangka pemecahan masalah secara operasional sebagai berikut. 1) Penyelenggaraan pelatihan selama tiga minggu tentang praktek berwirausaha a).memikiran produk usaha: b) memikirkan logo produk. 2) memberikan pelaporanpenjualan dan perputaran modal usaha. Kegiatan terjun lapangan adalah bagaimana para peserta membuat produk kemudian menjajakan produk usahanya. Kegiatan ini dilakukan selama tiga minggu, dimana setiap minggunya setiap kelompok peserta akan memaparkan hasil kegiatan berwirausahanya selama seminggu, mulai dari membuat produk hingga melakukan proses penjualan. Tidak hanya itu pelaporan hasil penjualan dan perputaran modal dilakukan setiap minggunya. Berdasarkan empat kelompok ada satu kelompok yang awalnya hanya mengeluarkan sedikit modal usaha tetapi pada minggu terakhir progres keuntungannya meningkat dari kelompok yang lain. Dimana kelompok yang lainnya mengalami fluktuatif keuntungan dikarenakan harus memutar kembali modalnya ketika bahan bahan usaha telah habis. Dan pada minggu terakhir semua kelompok atau empat kelompok semuanya mengalami keuntungan dari peputaran modal awal.

Kata Kunci : Pelatihan Wirausaha, Wirausaha Mahasiswa
\end{abstract}

\section{PENDAHULUAN}

Menghadapi perubahan dinamika sosial dan ekonomi seiring dengan perkembangan zaman dan teknologi, rasanya memulai perubahan juga harus dari proses pembelajaran perkuliahan. Menelisik dengan keadaan karena pandemi dan daya saing ekonomi yang harus memaksa setiap individu untuk siap bersaing. Dicetuskannya Mata Kuliah Kewirausahaan disemua program studi diharapkan mampu memberikan mahasiswa pengalaman belajar untuk 
Atirah, Wahyuddin, Reski Rahman Sriwijaya : Pendammpingan Wirausaha Sebagai Bentuk Pengembangan Diri Mahasiswa STAIN Majene

mengasah keterampilan tambahan diluar jurusan yang diambil, sehingga sebagai mahasiswa dan kelak menjadi lulusan, telah dibekali skill tambahan yang membuka alternatif lain untuk memperoleh penghasilan.

Dari 'ashim Ibn 'Ubaidillah dari Salim dari ayahnya Ia berkata bahwa Rasulullah Saw, bersabda: "sesungguhnya Allah menyukai orang Mukmin yang Berkarya" (H.R Al-Baihaqi) Berdasarkan hadist tersebut Karya yang dimaksudkan juga dapat digolongkan dari kemampuan untuk menciptakan usaha. Selain itu didalam Surah An-Nisa Ayat $9^{1}$

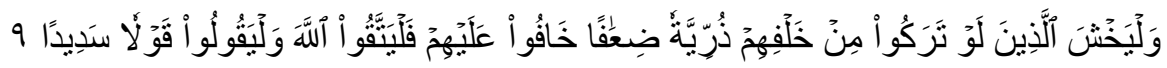

Terjemahnya: "Dan hendaklah takut kepada Allah orang-orang yang seandainya meninggalkan dibelakang mereka anak-anak yang lemah, yang mereka khawatir terhadap (kesejahteraan) mereka. Oleh sebab itu hendaklah mereka bertakwa kepada Allah dan hendaklah mereka mengucapkan perkataan yang benar” (Q.S 4:9)

Menafsirkan ayat tersebut dialam proses pembelajaran yang diharapkan maka sebaiknya Output dari mata kuliah Kewirausahaan didasarkan untuk memberikan pengalaman belajar mahasiswa dalam mengenal dan menumbuhkan ide, pembiasaan hingga sampai pada minat berwirausaha, layaknya sebuah pembelajaran Kewirausahan harus "memaksa" mahasiswa untuk berpraktek langsung dalam menumbuhkan, ide, mengembangkan gagasan ide dan betanggungjawab dalam pelaksanaan ide yang telah mereka kemukakan, sehingga dalam proses pengalaman belajar tersebut skill yang mereka dapatkan karena terjun langsung dalam praktek berwirausaha.

Memberikan ruang tambahan diluar jam perkuliahan bagi mahasiswa untuk memaksimalkan proses pembelajaran melalui program pelatihan untuk berwirausaha merupakan langkah yang bijaksana untuk memberikan pengalaman tambahan menunjang mata kuliah kewirausahaan. Kegiatan program pelatihan singkat untuk menjadi wirausaha diharapkan untuk memaksimalkan bekal tambahan diluar jam mata kuliah kewirausahaan agar membuat mahasiswa membiasakan diri untuk berfikir kreatif dalam berusaha.

Maka dari ini melalui pendampingan Mahasiswa sebagai peserta dalam Pengembangan Diri Melalui Kegiatan Berwirausaha untuk Menciptakan Pengalaman Belajar di luar Proses Perkuliahan Mahasiswa STAIN Majene.

\footnotetext{
${ }^{1}$ QS. Annisa (4) : 9
} 
Atirah, Wahyuddin, Reski Rahman Sriwijaya : Pendammpingan Wirausaha Sebagai Bentuk Pengembangan Diri Mahasiswa STAIN Majene

\section{METODE PELAKSANAAN}

1. Tujuan Kegiatan

Kegiatan ini dilakukan untuk melaksanakan program pengabdian masyarakat yakni menjadi pendamping untuk pengembangan diri mahasiswa sebagai peserta dalam berwirausaha. Kegiatan ini dilakukan selama 4 minggu dengan tujuan memberikan praktek praktek berwirausaha kepada mahasiswa mulai dari penentuan ide usaha, membuat logo, memasarkan hingga menghitung perputaran modal yang diharapkan akan memberikan pengalaman langsung tentang kegiatan berwirausaha.

2. Pendanaan

Pada program pendanaan didapatkan dari dana pribadi yang diberikan dalam bentuk modal usaha kepada para mahasiswa sebagai bentuk stimulus awal untuk memberikan motivasi lebih kepada mahasiswa untuk tidak terlalu berat memikirkan modal untuk memulai berwirausaha. Tentu saja dengan perjanjian selama program pendampingan, perputaran modal harus mendapatkan keuntungan diluar modal yang diberikan jika tidak maka modal awal harus dikembalikan para peserta. Hal ini dilakukan untuk memberikan tekanan terhadap produktifitas peserta dalam berwirausaha.

3. Sasaran

Sasaran dalam program pendampingan ini adalah mahasiswa STAIN Majene yang termotivasi untuk berwirausaha, baik yang belum, sedang maupun yang telah selesai mengampuh mata kuliah Kewirausahaan.

4. Narasumber Kegiatan

Narasumber dalam program pendampingan adalah Instruktur sendiri sebagai penyelenggara juga sebagai pendamping.

\section{TINJAUAN PUSTAKA}

Kewirausahaan Islam merupakan sebuah aspek kehidupan yang telah dikelompokkan kedalam masalah mu'amalah, dalam perkembangan di zaman moderen ini keadaan dunia usaha dalam kegiatan bertransaksi mulai bergeser nilai dan visinya (Bahri,2018) 2 .

Dalam Islam, baik itu dalam konsep maupun pada praktiknya, aktivitas kewirausahaan bukan hal yang baru, inilah yang sering diparktikkan oleh Rasulullah dan Istrinya serta para

${ }^{2}$ Bahri. 2018. Kewirausahaan Islam : Penerapan Konsep Berwirausaha dan bertransaksi Syariah dengan metode Dimensi Vertikal (Habblumminallah) dan dimensi Horizontal (Habblumminannas). Makro Jurnal Syariah dan Bisnis. Vol 1 (2). 
Atirah, Wahyuddin, Reski Rahman Sriwijaya : Pendammpingan Wirausaha Sebagai Bentuk Pengembangan Diri Mahasiswa STAIN Majene

sahabat. Islam tidak hanya berbicara kegiatan berwirausaha tetapi langsung mempraktikkannya didalam dunia nyata (Aprijon,2013) ${ }^{3}$.

Dalam pengertian secara sederhana Literasi Ekonomi adalah kepekaan terhadap kegiatan ekonomi. Kegiatan ekonomi bisa saja beruapa kegiatan memproduksi barang, menjual barang atau sebagai distributor atau sekarang dikenal dengan reseller atau bahkan dalam kegiatan konsumsi sekalipun seseorang harus tahu skala kebutuhan dan skala priotasnya sehingga setiap kegiatan ekonomi yang dilakukan selalu memiliki manfaat terutama diri sendiri kemudian barulah untuk orang lain dan lingkungan sekitar (Hasan,2021) ${ }^{4}$.

\section{METODE PELAKSANAAN PENGBADIAN}

\section{Tujuan Kegiatan}

Pelatihan praktek berwirausaha yang diangkat dalam kegiatan pengabdian kepada masyarakat ini bertujuan untuk memberikan pengalaman nyata kepada para mahasiswa untuk berwirausaha, yang diharapkan setelah pelatihan ini selesai memberikan stimulus untuk mahasiswa memiliki karir usaha sejak dini. Oleh karna itu, diusulkan kerangka pemecahan masalah secara operasional sebagai berikut. 1) Penyelenggaraan pelatihan selama tiga minggu tentang praktek berwirausaha a).memikiran produk usaha: b) memikirkan logo produk. 2) memberikan pelaporanpenjualan dan perputaran modal usaha.

Metode pembelajaran yang digunakan untuk mendukung keberhasilan program antara lain sebagai berikut:

a) Ceramah dan Tanya Jawab

Ceramah dan tanya jawab digunakan pada saat awal pertemuan memberikan motivasi dan dorongan memberikan informasi mengenai pentingnya wirausaha. Tanya jawab dilakukan untuk memberikan kesempatan kepada para peserta yang notabenenya adalah mahasiswa STAIN Majene untukbertanya terkait dengan program pelatihan ini.

b) LatihanPraktik

Pelatihan dilakukan untuk memberikan pengalaman nyata berwirausaha, mulai dari memikirkan produk, membuat produk, menjual hingga memperhitungkan keuntungannya.

\section{Sasaran}

\footnotetext{
${ }^{3}$ Aprijon. 2013. Kewirausahaan dan Pandangan Islam. Jurnal Menara. Vol 12 (1)

${ }^{4}$ Hasan,Muhammad. 2021. Isu-Isu Kontemporer Literasi Ekonomi dan Kewirausahaan. Penerbit. Penerbit: Tahta Media Grup.
} 
Atirah, Wahyuddin, Reski Rahman Sriwijaya : Pendammpingan Wirausaha Sebagai Bentuk Pengembangan Diri Mahasiswa STAIN Majene

Sasaran kegiatan ini adalah mahasiswa STAIN Majene yang sedang mempelajari Mata Kuliah Kewirausahaan.

\section{Narasumber}

Narasumber kegiatan ini adalah Dosen STAIN Majene yang bertugas sebagai instruktur dan pemberi motivasi kepada peserta pelatihan wirausaha.

\section{HASIL DAN PEMBAHASAN}

\section{Kegiatan Pra Praktek}

Kegiatan pra praktek dilakukan dua kali pertemuan pertemuan pertama merupakan penguatan mental untuk memulai berwirausaha. Menjelaskan dengan sederhana manfaat yang dapat peserta rasakan jika mereka benar-benar tekun untuk berwirausaha. Memberikan gambaran kepada peserta tentang banyaknya wirausahawan muda yang berhasil karena ketekunannya menjalankan usaha.

Selain memberikan motivasi pada pertemuan pra praktek pertama para peserta juga diberikan pesan moral dalam menjalankan kegiatan wirausaha mental utamanya adalah tidak malu atau berani untuk memulai kegiatan berwirausaha. Tahap motivasi diawal dilakukan sebagai bentuk pemberian penguatan mental untuk para peserta dalam melakukan kegiatan karena motivasi merupakan pemberian daya penggerak yang menciptakan kegairahan kerja kepada seseorang agar mereka mampu bekerjasama, bekerja efektif, dan terintegritas dengan segala daya upayanya dalam mencapai kepuasan (adha dkk :2019) ${ }^{5}$. Pengertian lain Motivasi adalah suatu yang pokok yang menjadikan dorongan bagi seseorang untuk bekerja. Motivasi merupakan kekuatan yang mendorong seseorang untuk melakukan suatu tindakan atau tidak yang pada hakikatnya ada secara internal dan eksternal posotif atau negarif, motivasi kerja adalah suatu yang menimbulkan dorongan kerja. (Sedarmayanti:2017:154) .

Pertemuan pra praktek kedua setelah dipertemuan pertama pemberian motivasi dan pengenalan tokoh wirausaha berhasil pada pertemuan kedua setiap peserta dibagi menjadi empat kelompok wirausaha, kemudian setiap dari anggota kelompok memikirkan ide usahanya sekaligus memikirkan logo untuk produk yang akan diproduksi. Hal tersebut memberikan pengalaman hingga pembelajaran kepada para peserta untuk bisa secara langsung memikirkan keselarasan ide

${ }^{5}$ Adha, R. N., Qomariah, N., \& Hafidzi, A. H. (2019). Pengaruh Motivasi Kerja, Lingkungan Kerja, Budaya Kerja Terhadap Kinerja Karyawan Dinas Sosial Kabupaten Jember. Jurnal Penelitian IPTEKS, 4(1), 47-62.

${ }^{6}$ Sedarmayanti. (2011). Tata Kerja dan Produktivitas Kerja. Bandung: Mandar Maju. 
Atirah, Wahyuddin, Reski Rahman Sriwijaya : Pendammpingan Wirausaha Sebagai Bentuk Pengembangan Diri Mahasiswa STAIN Majene

usaha dengan logo yang akan dibuat, sejatinya setiap logo akan memberikan gambaran dan tanda pengingat bagi konsumen untuk setiap produk usaha.

Pada pertemuan kedua pra praktek penyelenggara yakni instruktur memberikan bantuan modal usaha kepada setiap kelompok untuk membantu pemaksimalan modal dalam menjalan usahanya. Hal inidilakukan karena salah satu hambatan dalam memulai sebuah usaha adalah modal sehingga untuk memberikan bantuan dan memaksimalkan usaha bantuan modal sangat dibutuhkan.

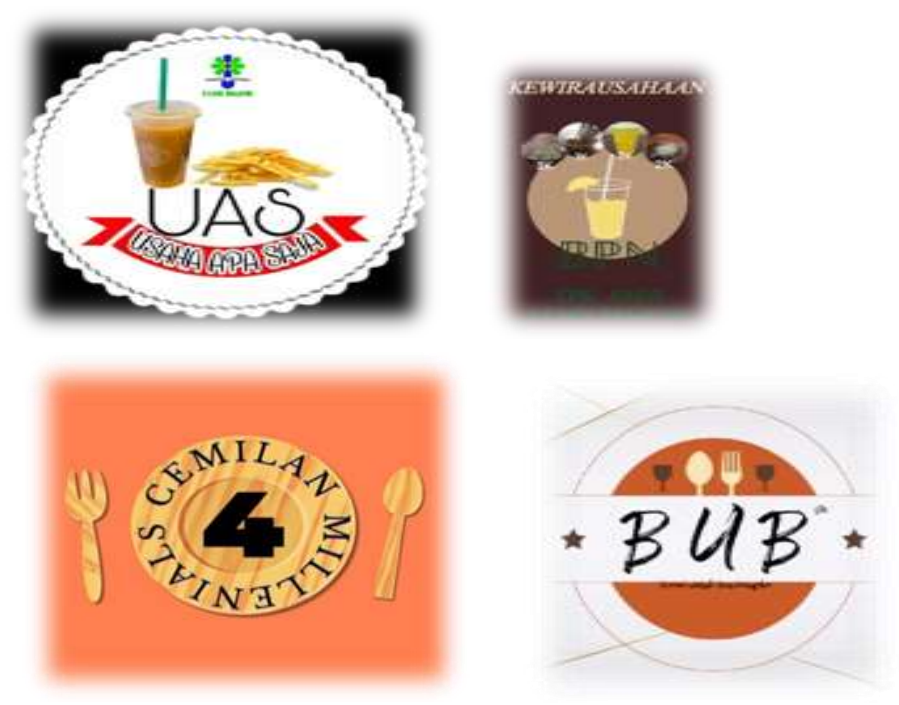

Gambar 1. Logo Produk

\section{Proses Terjun Lapangan}

Kegiatan terjun lapangan adalah bagaimana para peserta membuat produk kemudian menjajakan produk usahanya. Kegiatan ini dilakukan selama tiga minggu, dimana setiap minggunya setiap kelompok peserta akan memaparkan hasil kegiatan berwirausahanya selama seminggu, mulai dari membuat produk hingga melakukan proses penjualan. Tidak hanya itu pelaporan hasil penjualan dan perputaran modal dilakukan setiap minggunya.

Dari hasil pelatihan ada bebrapa hal yang berubah, kelompok peserta mahasiswa yang awalnya mempresentasikan produk yang akan dijual setelah mulai berirausaha ada yang mengganti produknya sesuai dengan kondisi yang menurut mereka lebih memudahkan, ada juga yang memilih untuk menambahkan produk usahanya mereka dengan menjadi reseller makanan. Keadaan terbut memberikan gambaran lain kepada para peserta bahwa menjadi seorang wirausaha bukan hanya sebagai pemikir tunggal dan ekskutor tunggal tetapi bagaimana berfikir efektif dan efisien secara kreatif untuk mendapatkan keuntungan. 
Atirah, Wahyuddin, Reski Rahman Sriwijaya : Pendammpingan Wirausaha Sebagai Bentuk Pengembangan Diri Mahasiswa STAIN Majene

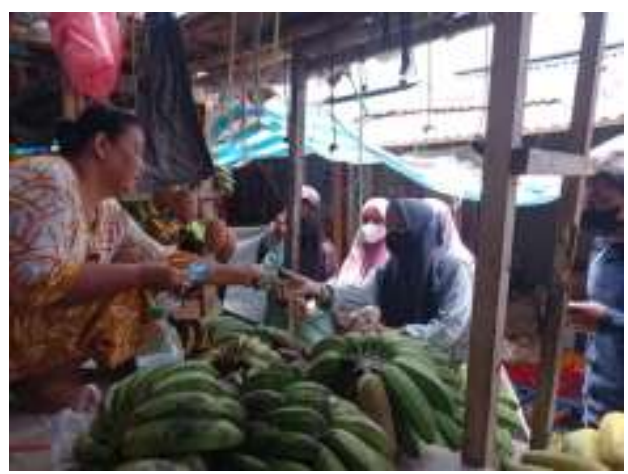

Gambar 2. Berbelanja bahan Baku

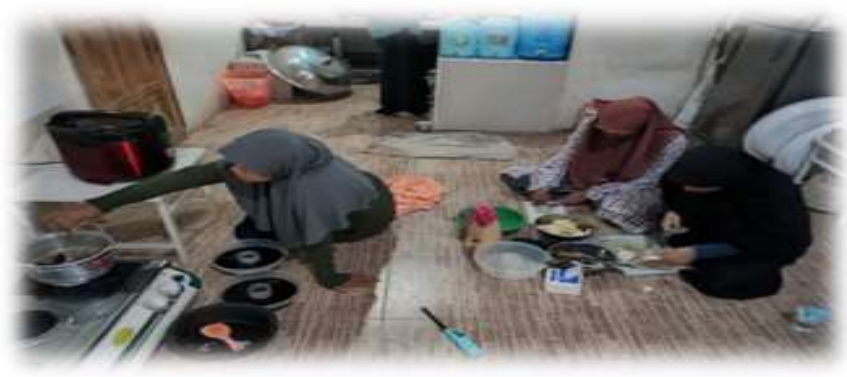

Gambar 3. Membuat Produk usaha

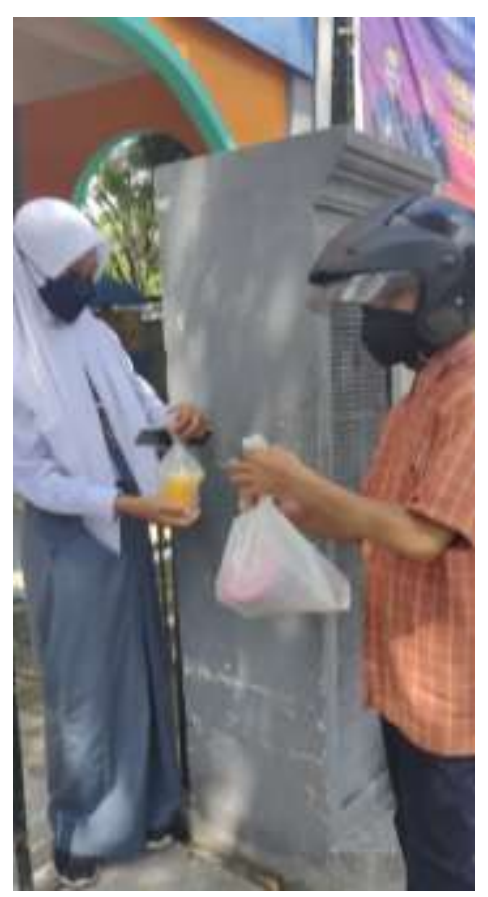

Gambar 4. Mangantarkan Orderan Konsumen

Al-Khidma: Jurnal Pengabdian Masyarakat Vol 1 No 2 Oktober 2021-Maret 2022 
Atirah, Wahyuddin, Reski Rahman Sriwijaya : Pendammpingan Wirausaha Sebagai Bentuk Pengembangan Diri Mahasiswa STAIN Majene

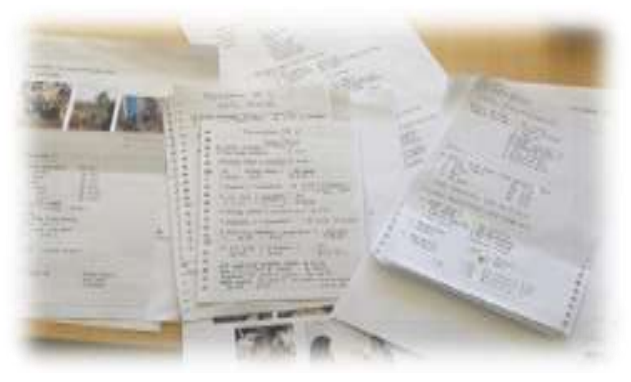

Gambar 5. Catatan Penjualan

\section{Perhitungan Perputaran Modal}

Perhitunan perputaran modal dilakukan setiap minggunya, artinya memberikan tekanan secara tidak langsung kepada peserta ketika kelompok lain memperlihatkan progres usahanya, setelah dilakukan praktek nyata berwirausaha, memang diminggu awal belum ada yang dapat dikatakan kembali modal tetapi dalam kenyataannya pemasukan mereka lebih banyak dari pengeluaran mereka.

Berdasarkan empat kelompok ada satu kelompok yang awalnya hanya mengeluarkan sedikit modal usaha tetapi pada minggu terakhir progres keuntungannya meningkat dari kelompok yang lain. Dimana kelompok yang lainnya mengalami fluktuatif keuntungan dikarenakan harus memutar kembali modalnya ketika bahan bahan usaha telah habis. Dan pada minggu terakhir semua kelompok atau empat kelompok semuanya mengalami keuntungan dari peputaran modal awal.

\section{SIMPULAN DAN SARAN}

Pelatihan kelompok wirausaha ini dilakukan untuk memberikan pengalaman nyata kepada mahasiswa dalam berwirausaha. Keadaan ini untuk menujang mata kuliaha kewirausahaan yang diharapkan akan memberikan stimulus kepada mahasiswa STAIN Majene untuk mengasah skill lain atau mengembangkan karir lain diluar juruan yang ditekuni.

Saran yang diberikan agar adanya tindak lanjut untuk mengembangkan organisasi atau unit yang berada dibawah naungan kampus STAIN Majene untuk mengembang, menjadi fasilitator atau hanya sekedar sebagai tempat konsultasi usaha mahasiswa yang di bimbing untuk lebih termotivasi dalam berwirausaha. 
Atirah, Wahyuddin, Reski Rahman Sriwijaya : Pendammpingan Wirausaha Sebagai Bentuk Pengembangan Diri Mahasiswa STAIN Majene

\section{UCAPAN TERIMA KASIH}

Kami ucapkan terima kasih yang sangat mendalam untuk para peserta kelompok wirausaha yang notabenenya adalah mahasiswa aktif dan au untuk meluangkan waktunya untuk mengikuti pelatihan praktek nyata berwirausaha. Tidak lupa kepada parnert dalam melakukan kegiatan pelatihan yang bertindak sebagai instruktur serta semua dosen yang telah memberikan masukan serta saran untuk program pendampingan berwirausaha mahasiswa.

\section{DAFTAR PUSTAKA}

Hasan,Muhammad. 2021. Isu-Isu Kontemporer Literasi Ekonomi dan Kewirausahaan. Penerbit. Penerbit: Tahta Media Grup.

Bahri. 2018. Kewirausahaan Islam : Penerapan Konsep Berwirausaha dan bertransaksi Syariah dengan metode Dimensi Vertikal (Habblumminallah) dan dimensi Horizontal (Habblumminannas). Maro Jurnal Syariah dan Bisnis. Vol 1 (2).

Aprijon. 2013. Kewirausahaan dan Pandangan Islam. Jurnal Menara. Vol 12 (1)

Sedarmayanti. (2011). Tata Kerja dan Produktivitas Kerja. Bandung: Mandar Maju.

Adha, R. N., Qomariah, N., \& Hafidzi, A. H. (2019). Pengaruh Motivasi Kerja, Lingkungan Kerja, Budaya Kerja Terhadap Kinerja Karyawan Dinas Sosial Kabupaten Jember. Jurnal Penelitian IPTEKS, 4(1), 47-62. 